pudiera haber hablado de "imágenes" o "tópicos" a secas. Por lo demás, el abismo que nosotros sentimos entre Alciato y Góngora sigue tan profundo al final del ensayo como al principio. - La comparación del paisaje gongorino con el paisajismo fisiognómico de Arcimboldo es de muy dudosa utilidad. ¿Y tiene algún sentido la mención de "Ios grandes temas búdicos"?

Alan Soons

University of the West Indies.

\title{
Marcelin Defourneaux, Pablo Olavide ou l'afrancesado (1725-1823). Presses Universitaires de France, París, 1959. 500 pp.
}

Es Olavide una de las figuras más atrayentes del siglo xvirI español. Nacido en el Perú, se traslada a España a los veintisiete años, es encarcelado por malversación de fondos, se casa con una viuda rica, hace un viaje a Francia y regresa con una biblioteca de 2,40o volúmenes. Se convierte en un "ilustrado" y en un hombre de acción, que pone en práctica las teorias de Aranda y Campomanes y hace una gran labor social en el sur de España. Pero a medida que sus reformas se hacen mejores y más eficaces, se va creando contra él una conspiración eclesiástica, que culmina en 1778 con un auto de fe en toda forma. Olavide huye a Francia, donde interviene activamente en los movimientos revolucionarios, a la vez que sigue tomando (en obediencia al mandato inquisitorial) clases de religión con un sacerdote que lo acompaña. Al sustituir Saavedra a Godoy en el ministerio, Olavide, rehabilitado, regresa a España y publica su Evangelio en triunfo, o historia de un filósofo desengañado (Valen-

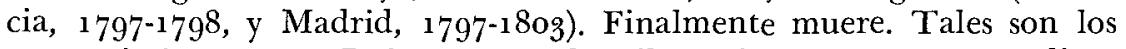
acontecimientos que Defourneaux describe e interpreta en su valioso libro.

Dos de los capítulos más acertados son el segundo y el tercero: viajes por Francia, descubrimiento de la cultura francesa, análisis de los libros que llevó a España quien pronto se convertiría en uno de los reformadores más audaces de su época. Me parece justísima la observación que hace Defourneaux de que, "a diferencia de los grandes reformadores "ilustrados» de la época de Carlos III, un Campomanes, un Moñino o un Jovellanos", Olavide es un étranger, es decir, un hombre nacido fuera de la Península y, por lo tanto tanto, extraño o ajeno a la gran tradición española (p. 53). Es un hombre cuya conformación espiritual es obra de Francia: de ahí que pueda convertirse en el auténtico afrancesado. Muy valiosa es también la precisión de las fechas, sobre todo en lo que respecta al primer regreso de Francia a España (1765), con una voluminosa biblioteca de economía y de política. De casa de Olavide saldrá una de las corrientes más ilustradas de la Península: a ella concurrirá Jovellanos, y sin duda allí leyó el asturiano muchos libros que más adelante le sirvieron para sus reformas: los fisiócratas, Voltaire, Bayle, Montesquieu, Rousseau... El dato es interesante si se piensa que habrá que esperar a 1780 para que Cadalso llegue a Salamanca y forme aquí uno de los centros ilustrados de España, desde donde irradiarán muchas 
de las ideas más audaces del momento, y que apenas entre 1787 y 1789 Luis Rico, José Rico y Juan Barco abrirán sus librerías en la misma Salamanca, convirtiendo a esta ciudad en un centro de pensamiento enciclopedista. (Cf. G. Demerson, Don Juan Meléndez Valdés et son temps, Paris, 1962). En Sevilla fijará Olavide su centro de operaciones, y allí pondrá en vigor todas las mejoras dictadas por su espíritu práctico. Lástima que Defourneaux no ponga más de relieve las relaciones entre Olavide, Aranda y Campomanes, a las cuales alude varias veces (v.gr., p. 251): esos tres hombres son, con O'Reilly y Cabarrús, los más atrevidos de su época.

Más interesante aún resulta la exhaustiva investigación que ha llevado a cabo el hispanista francés para estudiar el proceso inquisitorial contra el reformador peruano. Ya desde su llegada a Sevilla en ${ }_{17} 6_{5}$ se había interesado la Inquisición por ese hombre que llevaba en su equipaje una cantidad inaudita de libros. Por otra parte, la Iglesia estaba predispuesta contra él ya que, acorde con las intenciones regalistas de Aranda y Campomanes, el nuevo Asistente afirmaba la superioridad de la jurisdicción civil sobre la eclesiástica, y trabajaba en ese sentido, deseando acabar con las usurpaciones de los derechos del Estado por parte de las autoridades religiosas (cf. p. 294). Revela Defourneaux que el proceso se estuvo gestando durante mucho tiempo sin que nada trascendiera, y que se basó en tres puntos principales: la posesión de libros prohibidos, la presencia de pinturas indecentes en su casa, y su poco respeto al Santo Oficio (pp. 295 ss.). Las audiencias de testigos concluyeron en 1769 , y el asunto se mantuvo secreto durante tres años.

Muy atinadamente observa Defourneaux que el libelo La vida de don Guindo Cerezo (1776) no va enderezado sólo contra Olavide, sino contra todos aquellos que representaban la opinión o corriente ilustrada -ministros reformadores, prelados liberales, miembros de la Sociedad de Amigos del País-, todos aquellos que miraban al otro lado de la frontera, es decir, todos los afrancesados, cuyo tipo más acabado es el Intendente de Sevilla (p. 304). Señala también que el de Olavide es el último gran proceso de la Inquisición española, y que es importantísimo "por la calidad del reo, por lo que simbolizaba, por su persona misma, por la fecha en que se lleva a cabo: esos finales del xvin en que el «fanatismo» parecía haber sido extirpado definitivamente de todas las naciones ilustradas" (p. 341). De allí que toda la Europa de las Luces haya protestado contra el atropello.

En contra de la opinión más generalizada, Defourneaux sostiene que la conversión de Olavide al catolicismo fue sincera, y aporta pruebas de que su apología del cristianismo no se escribió con el mero propósito de ganarse el favor real y reivindicar su nombre (pp. 400 ss.). No advierte, sin embargo, la ironía de que el Evangelio en triunfo esté influido fundamentalmente por lecturas francesas: en esta ironía radica, a mi modo de ver, el meollo mismo de la Ilustración española.

IRIS M. ZAVALA 